\title{
In memoriam of Professor Krystyna Bernacka
}

On 1 April 2019 Prof. Krystyna Bernacka, Ph.D. passed away. She was a retired Head of the Rheumatology Clinic of the Medical University of Białystok, former Vice-President of the Polish Rheumatology Society, co-organiser and long-term Chairwoman of the Białystok Branch of the Polish Rheumatology Society.

Professor Krystyna Bernacka was born on 16 September 1927 in Hieronimów (a town on the border of Mazowieckie and Świętokrzyskie Voivodeship within the area of Ilża - Solec nad Wisłą - Ostrowiec Świętokrzyski). She began her education before the war and continued it under the German occupation during World War II in the form

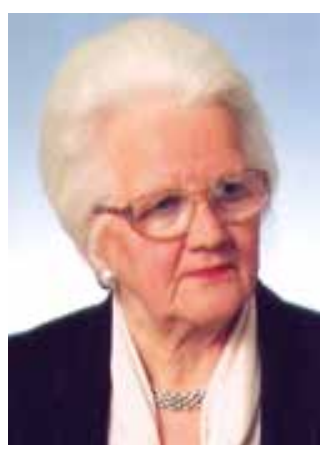
of secret education.

After the war, in the 1940's she started medical studies in Lublin and then studied at the Medical University in Warsaw, where in 1952 she was awarded a doctor's diploma. Soon afterwards, together with her husband Eugeniusz Bernacki, an excellent surgeon and later a professor, she came to Białystok. Here she completed her doctoral studies at the Medical University of Białystok (1966), was awarded her postdoctoral degree (1974) and later the academic titles of Associate Professor (1985) and Full Professor (1990).

Professor Krystyna Bernacka together with Prof. Beata Bogdanikowa (Head of the $1^{\text {st }}$ Internal Medicine Clinic and then the Internal Medicine Clinic) created the rheumatology team of the Medical University in Białystok. From the late 1960's she was the Head of the Department of Rheumatology and Internal Medicine Clinic and from 1980 until the age of 70 and her retirement she run the Rheumatology Clinic. The Rheumatology Department at the Medical University in Białystok was chronologically the second Polish academic rheumatology department (after Poznan's) and the third scientific and clinical centre of rheumatology after the Ministry of Health's Rheumatology Institute in Warsaw.

Professor Bernacka's scientific and research work focused on: the role of collagen in rheumatic diseases, progress in the diagnosis and treatment of rheumatoid arthritis, clinic for protein-glycoprotein disorders in rheumatic diseases, research on the pathogenesis of rheumatoid arthritis.

Under the supervision of Prof. Krystyna Bernacka a number of people obtained their doctoral degrees and three persons habilitated doctoral degrees. Professor participated actively in the staff training in the area of improving medical qualifications - many of her colleagues obtained specialised qualifications in internal medicine and rheumatology.

Professor Bernacka was an excellent organiser - also in her scientific work, an experienced clinician, a respected teacher and educator of academic youth. She shared a great deal of knowledge and scientific and clinical experience with her colleagues. Professor also devoted herself to organisational work for the academic environment - she was a long-term member of our University's Senate. She participated actively in the work of the District Medical Chamber in Białystok. Professor Krystyna Bernacka was very popular, respected and appreciated by Polish rheumatologists.

After her retirement in 1997, Prof. Bernacka was still active - she participated in scientific and training events as well as in the work of the Medical Chamber.

Two and a half years ago, following an unfortunate accident, Prof. Bernacka was confined to bed.

Professor Krystyna Bernacka received numerous awards and distinctions for her scientific achievements and didactic work, including the Knight's Cross of the Order of Polonia Restituta, the Golden Cross of Merit, the Badge for exemplary work in the Health Service.

We say goodbye to a wonderful woman, an outstanding scientist, a respected academic teacher and youth educator.

Stanistaw Sierakowski 